\title{
CHARACTERIZATION OF NUCLEOLAR - ORGANIZER REGIONS (NORS) IN BENIGN AND MALIGNANT EPITHELIAL BREAST LESIONS
}

By

Soheir M. Sirag and Wagiha M. Kandil

\author{
From \\ The Department of Pathology, Faculty of Medicine, \\ Mansoura University \\ Rscevied for Puplication : 11/12/1990
}

\section{INTRODUCTION}

Nucleolar organizer regions (NORS) are segments of DNA which are present in the nucieoli of cells and which possess ribosomal RNA genes. These genes are transcribed by RNA polymerase I to ribosomal RNA, (Egan et al., 1987 and Egan and Crocker, 1988). So, they are of vital significance in the protein synthesis by the cells. Accordingly, their number and or configuration may reflect cellular and nuclear activities that may characterize phenomena such as hyperplasia, transformation and neoplasia, (Ruschoff et al., 1989).

The argyrophilic staining of nucleolar organizer regions assdciated proteins (Ag - NORs) has largely been 261 the province of the cytogeneticist until recent modifications to the method which have enabled the technique to be applied to paraffin sections and appeared to possess potential value in the diagnostic histopathology, (Egan and Crocker, 1988). Many authors, (Ploton et al., 1986; Crocker and Shilbeck, 1987; Smith and Crocker, 1988 and Derenzini et al., 1989) have focused their attention mainly on the increased number of NORs to differentiate mal ignant from normal, reactive and benign neoplastic cells.

Therefore, the aim of the present study is to characterize NORs in benign and malignant epithelial breast lesions to facilitate the resolution of well - known diagnostic problems MANSOURA MEDICAL JOURNAL 
facing the histopathologist who is involved in the diagnosis of breast lesions. The simplicity and speed of this method if reliable would make it a useful mean in the diagnosis of breast lesions.

\section{MATERIAL AND METHODS}

72 epithelial breast lesions were investigated. Lymphocytes of the breast stroma as well as the endothelium of the blood vessels were examined and used as control cells.

Paraffin processed sections from the breast lesions were cut at thickness of $3-4 \mu$. They were dewaxed, rehydrated through ethanols to deionized water and then stained by the following :

(I) Haematoxylen and Eosin for:

a- Histopathological typing of the different lesions.

b- Histological grading of the malignant lesions. This was assessed by the point method according to Bloom and Richardson, (1957). c- Argyrophil silver colloid technique for NORS demonstration.

The staining solution was prepared by dissolving gelatin in $1 \%$ acquous formic acid at a concentration of $2 \%$. This solution then mixed $1: 2$ volumes with $50 \%$ aquous silver nitrate to give the final working solution. This was dropped on the sections and left for 60 minutes at room temprature, after which they were washed with deionized water. Then they were taken to xylene and mounted in D.P.X. No counterstain was used, (Crocker et al., 1988).

The Ag-NORs were seen as black dots or blebs within the nuclei of the cells and in each lesion 200 cells were examined using the oil immersion lens. The number of $\mathrm{Ag}$ - NORs per nucleus were counted and in the present study we counted all silver dots inside the nucleus but when lying in groups each cluster (almost agrregated nucleoli) treated as one dot, (Crocker et al., 1989). The mean number of Ag NOR5 was calculated and the differences between the different 
lesions and the control cells were submitted to analysis by the student's ttest.

In addition to the quantitation analysis of $\mathrm{Ag}$ - NORS careful observations as regards the distribution of $\mathrm{Ag}$ - NORS within the nucleus and the $\mathrm{Ag}$ - NORs sizes were performed in the present study.

\section{RESULTS}

(1) Histopathological typing :

The breast lesions included in the present study was classified into 36 benign and 36 malignant lesions. The benign lesions comprised 8 fibroadenomas, 3 papillomas, 10 sclerosing adenosis and 15 epitheliosis. The malignant lesions included 10 intraduct carcinomas and 26 invasive carcinomas. The latter comprised 20 schirrous, 2 encephaloid, 1 mucinous and 3 lobular carcinomas, (Table 1).

(2) Histological Grading :

Grade I (well differentiiated) Was encountered in 6cases of invasive carcinoma $(23.1 \%)$, Grade II (moderately differentiated) in 14 cases $(53.8 \%)$ and Grade III (poorly differentiated) in 6 cases $(231 \%)$, (Table II).

\section{(3) NORs Characterization :}

The cells of the benign epithelial breast lesions were characterized by a regularly clustered distribution of $\mathrm{Ag}$ NORs that are rather uniform in size. The Ag - NORS counts in the epithelial cells in this group of lesions revealed that fibroadenoma possessed the least count (mean $=1.58$ ). This is followed by papilloma (mean 1.93) and sclersoing adenosis (mean = 1.95). Epitheliosis had slightly higher counts than the other benign lesions (mean $=2.36$ but it was statistically insignificant comparing to the control cells (mean :-1.1).

In contrast, generally, the malignant lesions contained higher $\mathrm{Ag}$ NORs count than the benign lesions, the detailed results were illustrated in (Table 1). In addition to an increased number of NORs, malignant cells were characterized by an irregularly scattered distribution of NORS throughout the nucleus and by a heterogeneity in their sizes. 
It has been observed that, about half of the cases of both epitheliosis and intraduct carcinoma were overlapped in the NORs count range of 2 3 . However the remaining half of intraduct carcinoma clearly had a higher NORS count' (Fig.l).

Another finding in the present study which has attracted attention is that the mucinous carcinoma possessed few NORS number inspite of a general trend for the invasive carcinoma toward increased NORs counts.

Correlation between NORS and histological findings revealed that there was a clear trend towards higher counts in the higher histological grades, (Table 2)

\section{DISCUSSION}

NORs are loops of DNA present in the nucleoli of cells and which transcribes to ribosomal RNA. They are located on the short arms of 10 acrocentric group $G(13-15)$ and group $G$ (21 - 22) chromosomes. Therefore, theoritically, in man 20 NORs sites should be demonstrated in a normal Volume 21, 1991 diploid cells, (Stahl, 1982 and Crocker et al., 1988). But, however, the nucleolus is not a constant structure, for it dispersses during mitotic cell division and reorganizes afterwards, Immediately after mitosis the nucleus of a given cell will contain ten separate minute nucleoli , each formed around a NOR bearing chromosome but these associate rapidly to form the usual single nucleolus in the resting cell, (Field et al., 1984 and Crocker \& Nar, 1987). Since tumours behave differently and are functionally distinct, it is not surprising that the mean numbers of $\mathrm{Ag}$ NORS is also different, (Egan et al., 1987). This hypothesis is supported by an initial study performed by Ploton et al., (1986) that revealed two dots pernucleus of hyperplastic prostate but several in malignant prostatic cells. Similarly it has been shown that naevocellular naevi and melanocarcinoma have significantly different mean numbers of Ag-NORS (Crocker and Shilbeck, 1987). However, Ashworth and Helliwel (1988) contradict this hypothesis and denied that the number of $\mathrm{Ag}$ - NORS does not distinguish normal from either dysplastic 
epithelium or invasive carcinoma of the larynx.

In the present study we have applied the Ag - NORs technique to the different breast lesion to analyze their NORs characterization and to assess the usefullness of this novel technique in resolution of the problems related to the distinction between epitheliosis / papillomatosis and intraduct carcino$\mathrm{ma}$, scierosing adenosis and tubular carcinoma. It has been showed that in the present study, the cells of the benign epithelial lesions of the breast contained less mean Ag- NORs count. in addition, they were regularly distributed and uniform in size. On the other hand more numerous $\mathrm{Ag}$ - NORs were noticed in the cells of the malignant lesions with the exception of the mucinous variety. Moreover, they showed a characteristic distribution pattern as they were highly irregularly distributed within the nucleus and their sizes were very variable.

The less Ag- NORs number observed in the cells of the benign lesions can be explained by the fact that a benign lesion proliferate slowly with small number of cells in mitosis while the majority are resting or relatively inactive with $\mathrm{Ag}-\mathrm{NOR}$ remain tightly bound and aggregated within one or two nuclei. This explain also the regularity of Ag-NORs and the uniformity of their sizes.

In contrast, the apparent increase in the mean Ag-NORs count of the malignant cells could be explained by several factors. The first factor is that the cell proliferation is so active that a large compartment of the cells are continuously present in mitosis with resultant nucleolar dissociation and disaggregation, (Macartney, 1988). The second factor is that the elevated Ag-NORs count is attributed to the increased transcriptionally active ribosomal DNA sites in order to meet the increased demand for protein synthesis in these actively proliferating cells (Crocker et al.,1988 \& Hall et al.,1988). A third explanation provided by (Underwood \& Giri, 1988) is that there is a defect of nucleolar association after mitosis and the NORs remain dispersed. Lastly, the increased 
NORs count in the malignant cells may be due to increase in the cell ploidy (aneuploidy) with the resultant real increase of Ag-NORs bearing chromosomes, (Howat et al., 1988 and Underwood \& Giri, 1988).

From all these explanation the first one is strongly supported in a recent investigation performed by (Derenzini et al., 1989) who reported that the quantity of NORs is directly proportional to the division rate of the cells, being completely independent of chromosomal aneuploidy and the increased transcriptionally active DNA sites, Accordingly, we suggest that the less Ag-NORS count in the cells of the mucinous carcinoma may be attributed to that the cell function was directed toward secretion rather than division. This speculated explanation is an indication for the better differentiation and the well recognized favourable prognosis of the mucinous carcinoma reported by Norris and Taylor, (1965) and Gallager (1984).

It must be stressed that papilloma was distinguished from intraduct carcinoma and sclerosing adenosis from tubular carcinoma on the basis of their Ag-NORs count in the present study. However, inspite of the mean count of Ag-NORs of epitheliosis and intraduct carcinoma was statistically differ, but their ranges overlap at the region 2 - 3

Therefore this provide a potential for error in distinction between these two lesions. In this respect other criteria of Ag-NORs such as their distribution pattern and sizes may be of help in the resolution of such diagnostic problem.

In conclusion, our finding has been offered that Ag-NORs constitute a parameter that could facilitate the resolution of some well-known diagnostic problems in the breast when both quantitative and qualitative analysis are taken - together - in account. The rapidity of the method of staining, the ease of interpretation and being inexpensive add advantages to it. Furthermore, since NORs number increased with the grade of malignancy, therefore it can provide an information Volume 21, 1991 
about the proliferative status of the cells and so it can be used as a prognostic factor supplementary to other prognostic indices in breast carcinoma

\section{SUMMARY}

This study Was conducted on 36 benign and 36 malignant epithelial lesions. They were processed as paraffin sections and atained with :

1) $\mathrm{Hx}$. \& E. for :

a- Histopathological typing of the different lesions

b- Histopathological grading of the rnalignant lesions.

2) Argyrophil silver colloid technique for NORs demonstration .
It has been shown that, in the present study, NORs can differentiate between benign and malignant lesions, a finding which facilitate the resolution of some well-known diagnoctic problems in the breast. The rapidity of the method of staining, the ease of interpretation and being inespensive add advantages to it. Moreover, NORs number in malignant lesions can provide an information about the proliferative status of the cells and so. it can be used as a prognostic factor supplementary to other prognostic indices in breast carcinoma. 


\begin{tabular}{|c|c|c|c|}
\hline \multirow{5}{*}{ 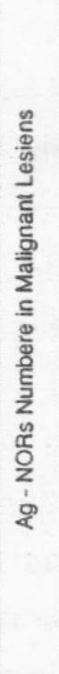 } & 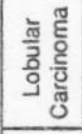 & $\underset{\substack{n \\
m}}{\stackrel{d}{d}}$ & ํㅠㅁ \\
\hline & 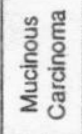 & के & $\stackrel{\text { }}{\circ}$. \\
\hline & 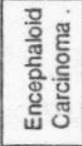 & 角 & 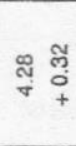 \\
\hline & 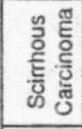 & 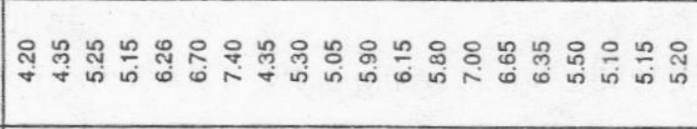 & ஜ \\
\hline & 乡气 & 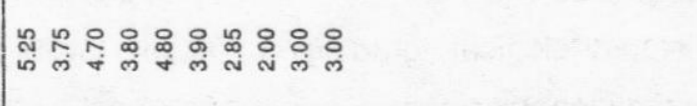 & $\underset{\text { ह }}{\bar{m}} \stackrel{\text { d }}{+}$ \\
\hline \multirow{4}{*}{ 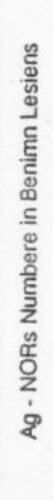 } & 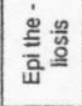 & 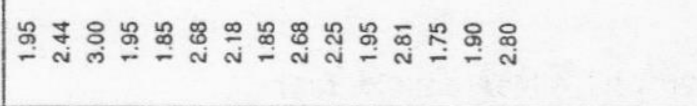 & 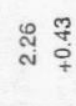 \\
\hline & 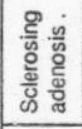 & ํㅜㄴ 은 & $\stackrel{\infty}{\stackrel{\infty}{\circ}}$ \\
\hline & 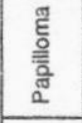 & 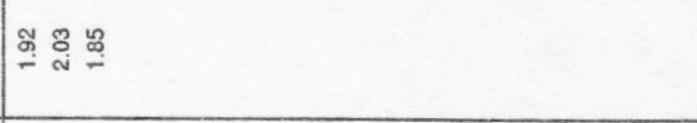 & 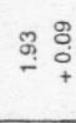 \\
\hline & 递 & 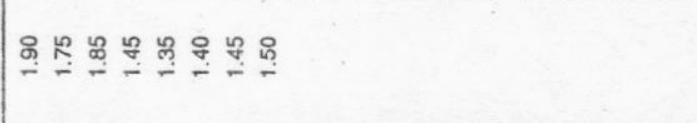 & 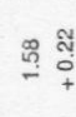 \\
\hline \multicolumn{2}{|c|}{$\begin{array}{l}\text { ळू } \\
\text { हूँ है } \\
\text { के }\end{array}$} & - & 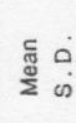 \\
\hline
\end{tabular}


Table ( 2): The relationship between Ag-NORs and the histological grades in invasive breast carcinoma

\begin{tabular}{|c|c|c|c|}
\hline Grade & No. & $\%$ & $\begin{array}{c}\text { Ag- NORs Count } \\
\text { (Mean + S.D ) }\end{array}$ \\
\hline Grade I & 6 & 23.1 & $4.1+1.12$ \\
Grade II & 14 & 53.8 & $5.18+0.98$ \\
\hline Total & 6 & 23.1 & $6.2+1.04$ \\
\hline
\end{tabular}

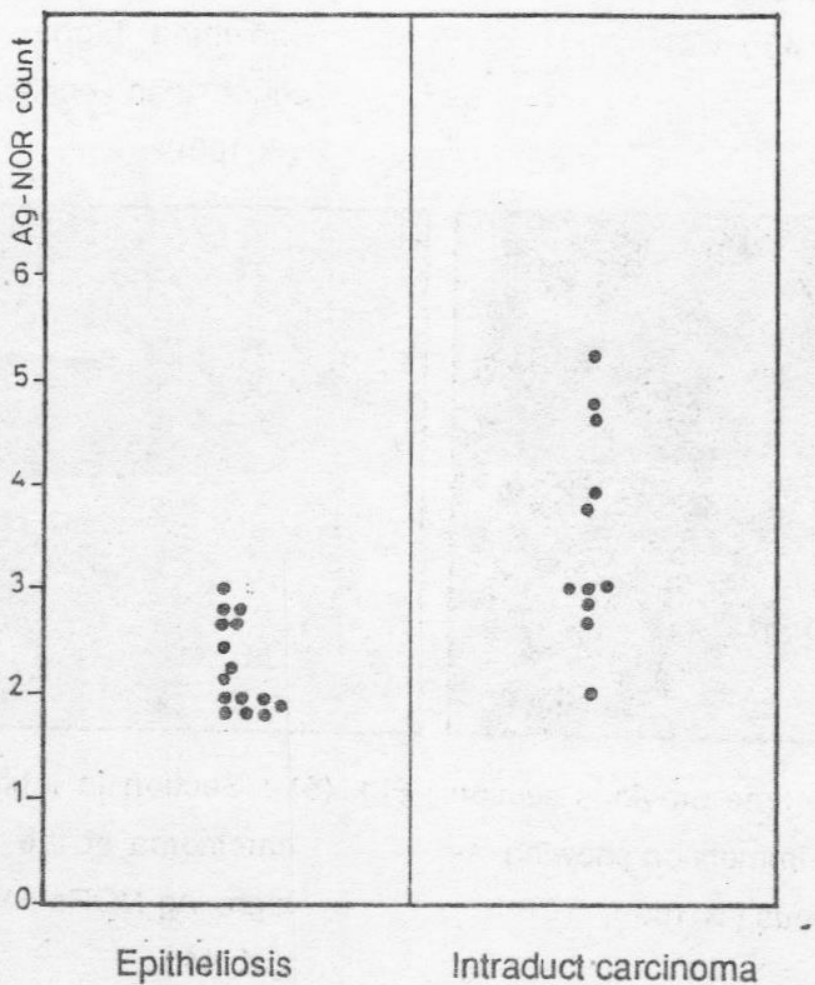

Fig.1: Illustrates the distribution of the cases of epitheliosis and intraduct carcinoma among Ag-Nor count range. 


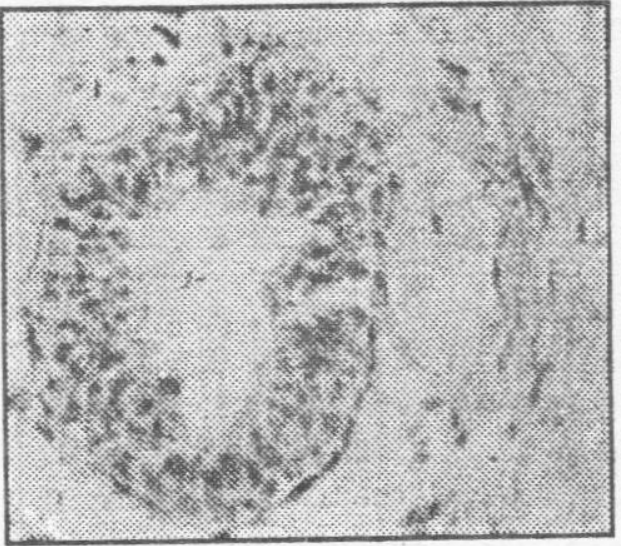

Fig. (2) : Section of the breast showing epitheliosis Argyrophilic stain (X 40).

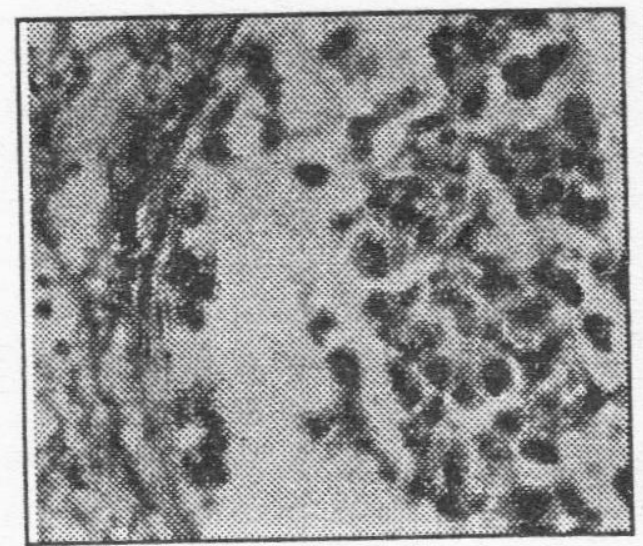

Fig. (3) : The same previous section with oil immersion showing 1 $2 /$ nucleus ( $X 100$ ).

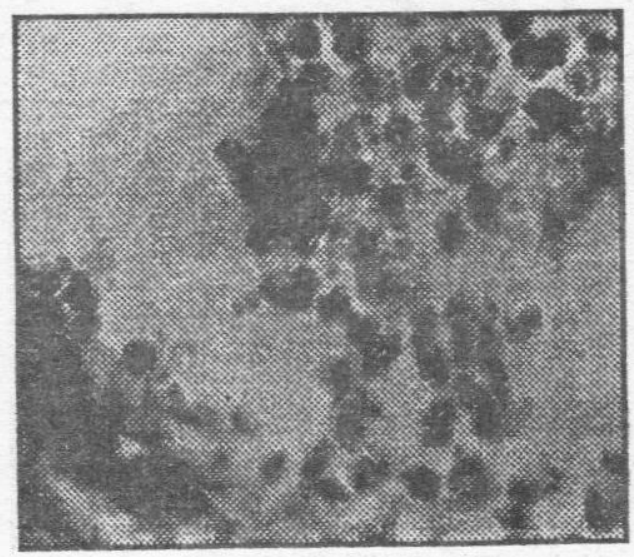

Fig. (4) : Section in intraduct carcinoma of the breast. The cells showning higher Ag-NORs count than epitheliosis (X100).

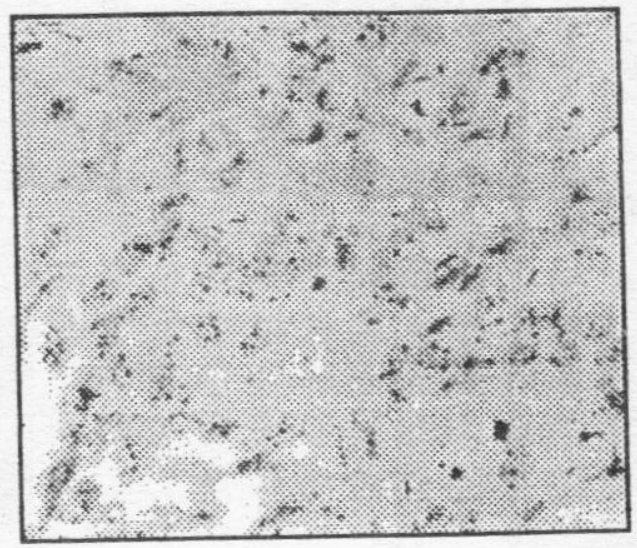

Fig. (5) : Section in infiltrating duct carcinoma of the breast with high Ag-NORs in their cells $(X: 44)$. 


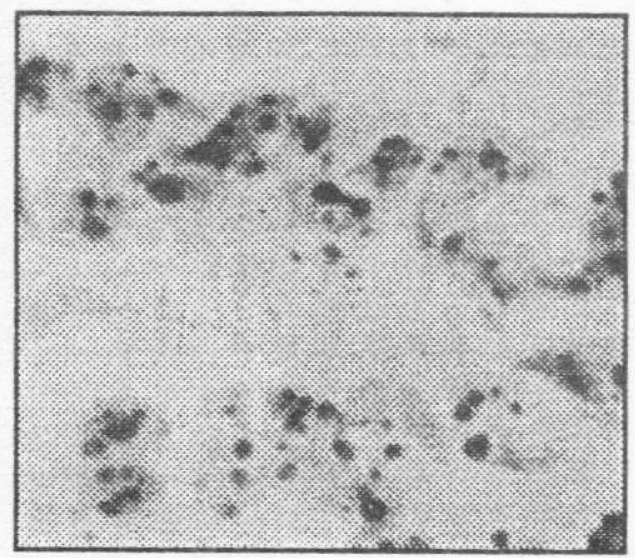

Flg. (6) : The same previous section with higher magnification (X100).

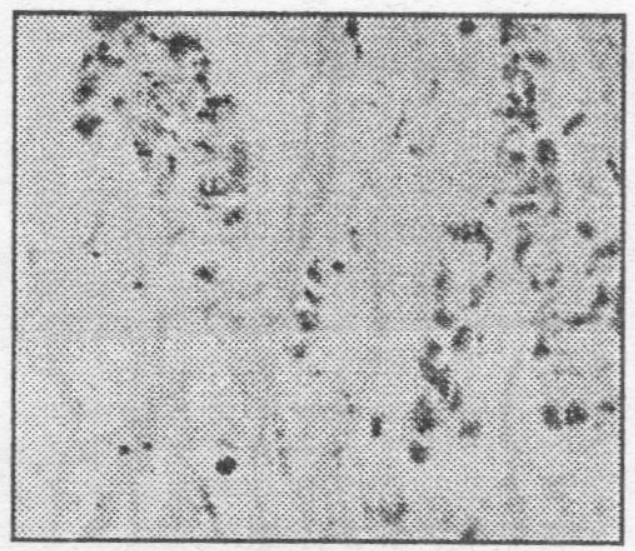

Fig. (7) : Section in lobular breast carcinoma. The cells show high Ag - NORs count $(X 40)$.

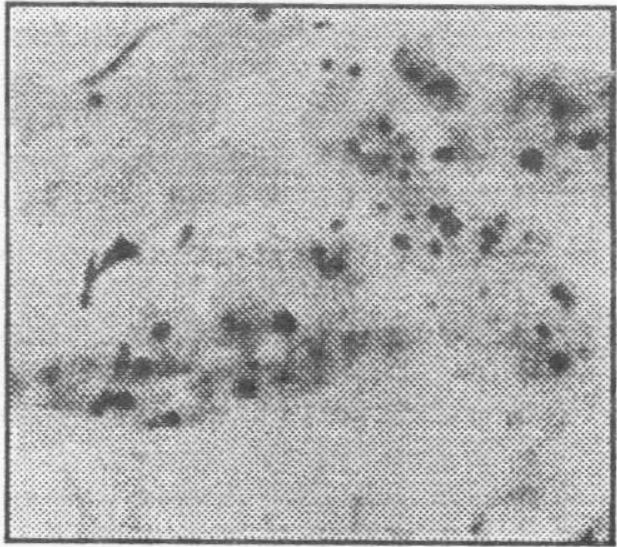

Flg . (8) : The same previous section with higher magnification (X 100).

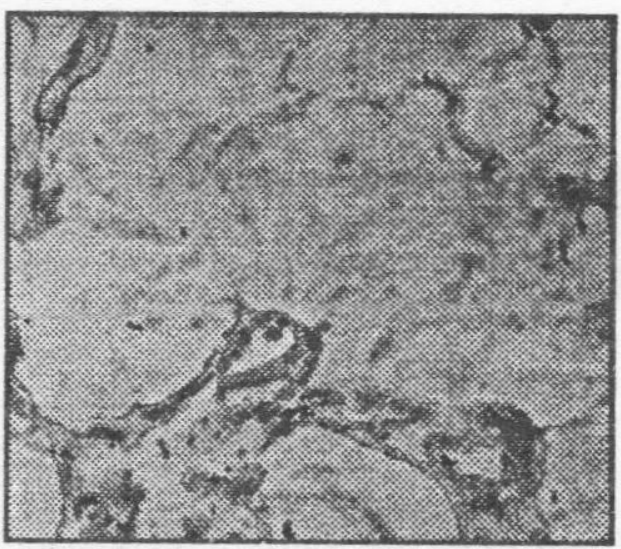

Flg . (9) : Section in mucinous carcinoma of breasst showing low $\mathrm{Ag}$ - NORs count $(X 40)$. 
272 CHARACTERIZATION OF NUCLEOLAR - ORGANIZER etc...

\section{REFERENCES}

Ashworth, M.T. and Helliwell, T.R.

(1988) : J. Pathol. $154: 64$ -

$65 \mathrm{~A}$.

Bloom, H.J. and Richardson, W.W. (1957) : Br. J. Cancer, 11 : $459-377$.

Crocker, J. and Nar, P. (1987) : J. Pathol., 151 : 111 - 118.

Crocker, J . and Shilbeck, N. (1987):

J. Clin. Path. $40: 885$ - 889.

Crocker, J.; Maccartney J,C. and Smith, P.J. (1988): J. Pathol. $154: 151-156$.

Crocker, J.; Baidy D,A.R. and Egan, M.J. (1989): J. Pathol., 158: $185-188$.

Derenzini, M.; Nardi, F. Farabegol, F.O, Attinetti, A.; Roncaroli F. and Bussolati G. (1989) : Acta cytologica, 23, 4: 491 - Norris H.J, and Taylor H.B. (1965) : 498.
Egan M.J.; Raafat F.; Crocker J. and Smith K. (1987) : J. Pathol. 153: 275 - 280 .

Egan M.J. and Crocker J. (1988): J. Pathol. 154 : 247 - 253.

Field D.H.; Filzgerald P.H.; Sin F.Y.T. (1984) : Cytobias. 41 : $23-33$.

Gallager, H.S. (1984): Canc er, 53 : 623

Hall P.A.; Crocker J. ; Watt A. and Stansfeld A.G. (1988): Histopathol. $12: 373-381$.

Howat A.J. ; Giri D.D. ; Wright A.L. and Underwood J.C.E. (1988) : J. Pathol,, $156: 227$ $-232$.

Macartney J.C. (1988) : J. Pathol., $156: 7-8$.

Cancer, $18: 879$. 
Ploton, D.; Menager M.; Jeannes- Smith R. and Crocker, J. (1988) : son P.; Himber G.; Pigean Histopathology, $12: 113$ F. and Adent J. (1986) : 125.

Histochem. J. $18:$ 5-14.

Stahl, A. (1982) : The nucleolus and Ruschoff, J.; Plate,K.; Bittinger, A. and Thomas, C. (1989): Pathol. Res. and Practice : 878-885.

\begin{abstract}
nucleolar chromosomes in : Jordan E.G., Cullis C,A. eds. The nucleolus. Cambridge University Press P. 1-24.
\end{abstract}

Underwood,J.C.E. and Giri, D.D. (1988) : J. Pathol., 155 : 95 96. 
خصائص المناطق المنظمة لبناء البروتين والموجودة فى نوبات

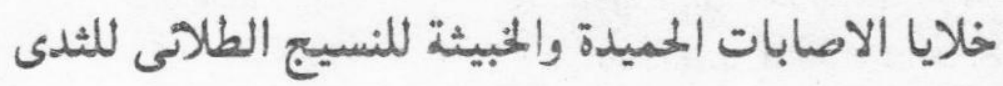

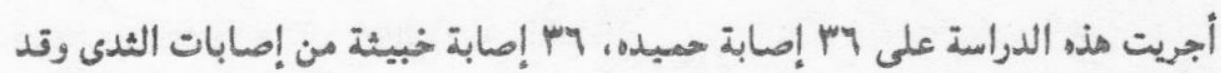

تم إعداد شرائح من هذه العينات بطريقة البرانين وتم صبغها بالطرق الآتية :

1- هيماتوكسلين والايوسبن لتشخيص نوع الإصابة وكذلك معرفة درجة التباين النوعى

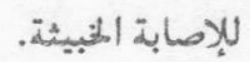

Y Y صبغة الفضه الغرويه (الارجيروفيل) للراسة خصائص المناطق المنظة الموجودة فى

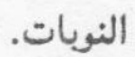

وقد نوقشت النتائج وثبت أن هذه المناطق ممكن بها التمبيـز بين الأورام الحميـدة

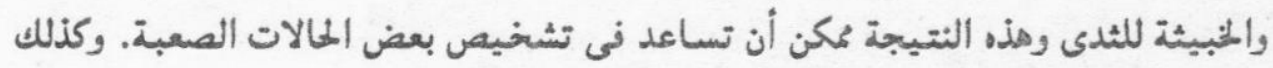

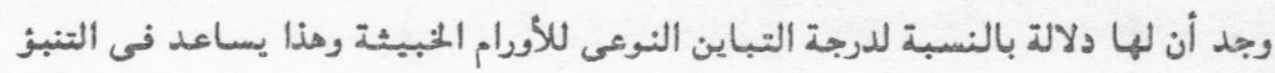

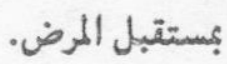

ويضاف إلى ذلك سهولة هذه الطريقة ورخص تكلنتها وامكانية تطبيقها على الثرائح المجهزة للفحص الروتينى تحت الميكروسكوب الضونى. 